\title{
George Pólya: el razonamiento plausible
}

\author{
Vernor Arguedas T. \\ vernor.arguedas@ucr.ac.cr \\ Escuela de Matemática \\ Universidad de Costa Rica
}

\section{Resumen}

Presentamos algunos aspectos de la vida del gran matemático , Geoge Pólya así como sus ideas acerca de las técnicas para enseñar matemáticas por medio de la resolución de problemas y una aproximación a su concepto de pensamiento plausible.

Palabras clave: Pólya, razonamiento plausible, solución de problemas.

\section{Abstract}

We present some aspects of the life of the great mathematician, Pólya Geoge and their ideas about techniques for teaching mathematics through problem solving and an approach to his concept of plausible reasoning.

Keywords: Pólya, plausible reasoning, problem solving.

\subsection{Introducción}

George Pólya (1887-1985) fue un distinguido matemático austro húngaro, suizo norteamericano y excepcional educador de las matemáticas, pocas personas han tenido una influencia tan grande dentro del contexto de enseñar las matemáticas vía la solución de problemas ajustados al proceso de enseñanza aprendizaje.

Una idea de la obra y vida de Pólya se encuentra en http://es.wikipedia.org/ wiki/George_Pólya.

Su filosofía y metodología en esta materia se encuentran en varios libros entre los cuales citamos: Cómo plantear y resolver problemas, Matemáticas y razonamiento plausible, I,II y el Descubrimiento Matemático I, II.

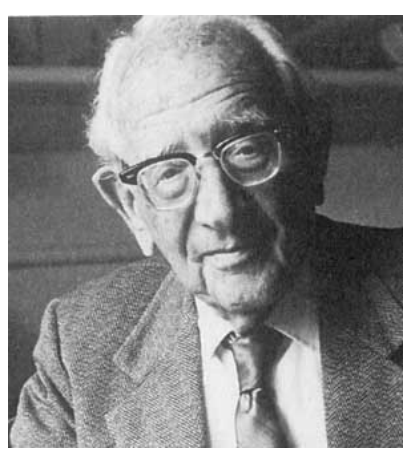


El libro Cómo plantear y resolver problemas publicado en 1945, ha vendido más de un millón de ejemplares y se ha traducido al menos a 17 lenguas. Lo citan matemáticos, psicólogos, pedagogos, filósofos y didactas. Es el primero de una trilogía en el que el autor va exponiendo sus ideas sobre cómo ayudar a los alumnos a pensar por sí mismos, a resolver problemas, al tiempo que trata de desentrañar las reglas del "pensamiento plausible" En ellos vierte su rica experiencia como matemático y como profesor (Polya tiene 58 años cuando publica Cómo plantear y resolver problemas), tratando de hacer explícitas preguntas y sugerencias que, según él, son "naturales, sencillas, obvias, y nacen del sentido común"

Polya indica cuatro fases en el proceso de resolver problemas: Comprender el problema, concebir un plan, ejecutar el plan y examinar la solución. Además, asocia una lista de preguntas a cada una de sus fases que incluyen ideas acerca del uso de diversos métodos heurísticos (estrategias que pueden ayudar a avanzar o resolver un problema). Presenta varios ejemplos en los que se ilustra el uso de diversos métodos heurísticos.

Los heurísticos identificados por Polya se enmarcan en comunicar su propia experiencia como matemático para resolver problemas, y pensaba que las estrategias y preguntas de un experto "con gran experiencia en la resolución de problemas" podían ser modeladas por los profesores en las aulas.

Polya creía que bajo la guía del profesor, los estudiantes podían internalizar el proceso de cómo un matemático dialoga consigo mismo durante el proceso de solución y utilizarlo de manera natural sin ayuda externa.

\subsection{Etapas y Heurísticas.}

Las etapas y heurísticas que presenta Polya se muestran a continuación:

\subsubsection{Comprender el problema}

- ¿Cuál es la incógnita?

- ¿Cuáles son los datos?

- ¿Cuál es la condición?

- ¿Es la condición suficiente para determinar la incógnita?

- ¿Es insuficiente?

- ¿Redundante?

- ¿Contradictoria?

- Concebir un plan

- ¿Se ha encontrado con un problema semejante? ¿O ha visto el mismo problema planteado en forma ligeramente diferente?

- ¿Conoce un problema relacionado con éste? ¿Conoce algún teorema que le pueda ser útil? Mire atentamente la incógnita y trate de recordar un problema que le sea familiar y que tenga la misma incógnita o una incógnita similar.

George Pólya: el razonamiento plausible. Vernor Arguedas T.

Derechos Reservados (C 2012 Revista digital Matemática, Educación e Internet (www.tec-digital.itcr.ac.cr/revistamatematica/) 
- He aquí un problema relacionado al suyo y que se ha resuelto ya. ¿Podría usted utilizarlo? ¿Podría utilizar su resultado? ¿Podría emplear su método? ¿Le haría a usted falta introducir algún elemento auxiliar a fin de poder utilizarlo?

- ¿Podría enunciar el problema en otra forma? ¿Podría plantearlo en forma diferente nuevamente? Refiérase a las definiciones.

- Si no puede resolver el problema propuesto, trate de resolver primero algún problema similar. ¿Podría imaginarse un problema análogo un tanto más accesible? ¿Un problema más general? ¿Un problema más particular? ¿Un problema análogo? ¿Puede resolver una parte del problema? Considere sólo una parte de la condición; descarte la otra parte; ¿en qué medida la incógnita queda ahora determinada? ¿En qué forma puede variar? ¿Puede usted deducir algún elemento útil de los datos? ¿Puede pensar en algunos otros datos apropiados para determinar la incógnita? ¿Puede cambiar la incógnita? ¿Puede cambiar la incógnita o los datos, o ambos si es necesario, de tal forma que la nueva incógnita y los nuevos datos estén más cercanos entre sí?

- ¿Ha empleado todos los datos? ¿Ha empleado toda la condición? ¿Ha considerado usted todas las nociones esenciales concernientes al problema?

\subsubsection{Ejecución del plan}

- Al ejecutar su plan de la solución, compruebe cada uno de los pasos.

- ¿Puede usted ver claramente que el paso es correcto? ¿Puede usted demostrarlo?

\subsubsection{Examinar la solución}

- ¿Puede usted verificar, el resultado? ¿Puede verificar el razonamiento?

- ¿Puede obtener el resultado en forma diferente? ¿Puede verlo de golpe? ¿Puede usted emplear el resultado o el método en algún otro problema?

La obra de Polya ha ayudado a muchos profesores a redescubrir el sentido de la educación matemática y a los investigadores a poner los cimientos de una teoría que explique el proceso de resolución de problemas .

Los cuatro elementos anteriores tienen un precedente histórico en una figura que hemos citado varias veces: Rene Descartes y del cual recordamos rápidamente su método.

\subsection{El método, según Descartes}

El método, así entendido, supone en primer lugar un criterio de verdad, un criterio que permita "no tomar nunca lo falso por verdadero". Ese criterio es, para Descartes, la evidencia. Por ello, cuando formula sus cuatro famosas reglas del método, enuncia en primer término la que se refiere a ese criterio de la verdad:

1. No aceptar como verdadero lo que con toda evidencia no reconociese como tal, no aceptando como cierto sino lo que se presentase a mi espíritu de manera tan clara y distinta, que acerca de su certeza no pudiese caber la menor duda.

Las otras tres reglas son más rigurosamente metodológicas, si por método se entiende el conjunto de operaciones que orienten la búsqueda de la verdad en una ciencia cualquiera:

1. Dividir cada una de las dificultades en tantas partes como sea necesario para resolverlas. 
2. Ordenar los conocimientos desde los más sencillos, subiendo por grados, hasta llegar a los más compuestos (y suponiendo un orden en aquellos que no lo tengan por naturaleza).

3. Hacer enumeraciones tan completas y generales, que den la seguridad de no haber incurrido en ninguna omisión.

Descartes busca un método para encontrar la verdad -tarea enorme-, Polya nos presenta un guía para abordar la solución de un problema, una metodología que es válida más allá del mundo de las matemáticas pues se puede utilizar en cualquier disciplina. Hay un factor subjetivo muy importante en su metodología. Pólya quiere que los alumnos vean como piensa un matemático, cómo ataca un problema, cómo conjetura, cómo busca ejemplos y contraejemplos. El nacimiento de cualquier resultado es un momento de gran importancia, se puede siempre preguntar: ¿cómo se hizo?, ¿a qué teorías se recurrió? Y muchas preguntas más. No olvidemos que Euclides en sus Porismas nos planteaba la existencia de problemas que podían tener o no tener solución.

Insistiendo sobre estos temas Pólya nos dejó sus diez mandamientos para quienes enseñan:

1. Demuestre interés por su materia. Si el profesor se aburre, toda la clase se aburrirá.

2. Domine su materia. Si un tema no le interesa personalmente, no lo enseñe, porque no será capaz de enseñarlo adecuadamente. El interés es una condición necesaria, pero no suficiente. Cualesquiera que sean los métodos pedagógicos utilizados, no conseguirás explicar algo claramente a tus estudiantes si antes no lo haz comprendido perfectamente. De ahí este segundo mandamiento. El interés es el primero, porque, con algunos conocimientos junto con una falta de interés, se puede uno convertir en un profesor excepcionalmente malo.

3. Sea instruido en las vías del conocimiento: el mejor medio para aprender algo es descubrirlo por sí mismo. Se puede obtener gran provecho de la lectura de un buen libro o de la audición de una buena conferencia sobre la psicología del acto de aprender. Pero leer y escuchar no son absolutamente necesarios y en todo caso no son suficientes : hay que conocer las vías del conocimiento, estar familiarizados con el proceso que conduce de la experiencia al saber, gracias a la experiencia de vuestros propios estudios y a la observación de vuestros estudiantes.

4. Trate de leer en el rostro de sus estudiantes, intente adivinar sus esperanzas y sus dificultades; póngase en su lugar. Aunque uno se interese por el tema, lo conozca bien, se comprendan los procesos de adquisición de los conocimientos, se puede ser un mal profesor. Es raro, pero muchos hemos conocido profesores que, siendo perfectamente competentes, no eran capaces de establecer contacto con su clase. Ya que la enseñanza del uno debe acompañarse por el aprendizaje del otro, tiene que existir un contacto entre el Profesor y el estudiante. La reacción del estudiante a tu enseñanza depende de su pasado, de sus perspectivas y de sus intereses. Por lo tanto, téngase en consideración lo que saben y lo que no saben; lo que les gustaría saber y lo que no les importa; lo que deben conocer y lo que no importa que no sepan.

5. No les de únicamente "saber", sino "saber hacer", actitudes intelectuales, el hábito de un trabajo metódico. El conocimiento consiste, parte en "información" y parte en "saber hacer". El saber hacer es el talento, es la habilidad en hacer uso de la información para un fin determinado; se puede describir como un conjunto de actitudes intelectuales; es la capacidad para trabajar metódicamente. En Matemáticas, el "saber hacer" se traduce en una aptitud para resolver problemas, construir demostraciones, examinar con espíritu crítico soluciones y pruebas. Por eso, en Matemáticas, la manera cómo se enseña es tan importante como lo que se enseña.

6. enseñarles a conjeturar. Primero imaginar, después probar. Así es como precede el descubrimiento, en la mayor parte de los casos. El profesor de Matemáticas tiene excelentes ocasiones para mostrar el papel de la conjetura en el campo del descubrimiento y hacer así que los estudiantes adquieran una actitud intelectual fundamental. La conjetura razonable debe estar fundada en la utilización juiciosa de la evidencia inductiva y de la analogía, y encierra todos los conocimientos plausibles que pueden intervenir en el método científico. 
7. enseñarles a demostrar. "Las matemáticas son una buena escuela de razonamiento demostrativo". De hecho, la verdad va más allá: las matemáticas pueden extenderse al razonamiento demostrativo, que se infiltra en todas las ciencias desde que alcanzan un nivel matemático y lógico suficientemente abstracto y definido.

8. En el problema que estés tratando, distinguir lo que puede servir, más tarde, la resolver otros problemas, intentad revelar el modelo general que subyace en el fondo de la situación concreta que se afronte. Cuando presentéis la solución de un problema, subrayar sus rasgos instructivos. Una particularidad de un problema es instructiva si merece ser imitada. Un aspecto bien señalado, en un problema, y vuestra solución puede transformarse en un modelo de resolución, en un esquema tal que, imitándo, al estudiante pueda resolver otros problemas.

9. No revele de pronto toda la solución; deje que los estudiantes hagan suposiciones, déjeles descubrir por sí mismos siempre que sea posible. He aquí una pequeña astucia fácil de aprender: cuando se empieza a discutir la solución de un problema, deje que los estudiantes adivinen su solución. Quien tiene una idea o la ha formulado, se ha comprometido: debe seguir el desarrollo de la solución para ver si lo que ha conjeturado es exacto o no, con lo que no puede despistarse. Voltaire decía: "El secreto para ser aburrido es decirlo todo".

10. No inculquen por la fuerza, sugieran Se trata de dejar a los estudiantes tanta libertad e iniciativa como sea posible, teniendo en cuenta las condiciones existentes de la enseñanza. Dejen que los estudiantes hagan preguntas; o bien planten cuestiones que ellos mismos sean capaces de formular. Dejen que los estudiantes den respuestas; o bien den respuestas que ellos mismos sean capaces de ofrecer.

\section{4 ¿Qué es plausible?.}

En su método con 4 etapas y en su decálogo está la esencia de lo plausible. Plausible es aquello que puede ser, pero siempre debe ser una expresión o una afirmación correcta de manera formal que puede ser investigada, aceptada o rechazada, en nuestra disciplina rechazamos usualmente vía contraejemplos y en algunas ocasiones demostrando que la expresión es falsa y verdadera simultáneamente. Esto presupone que estamos en un universo lógico en el cual no existen expresiones correctamente construidas que sean simultáneamente falsas y verdaderas.

En un mundo regido por leyes de la mecánica cuántica este argumento no sería correcto habría que hacer algunos ajustes.

En el pensamiento plausible a la hora de conjeturar se acepta "el chispazo", la idea brillante que de una manera un tanto deus ex machina resuelve el problema.

Hofstaedter en su libro Gödel, Escher, Bach: una eterna y dorada trenza nos presenta también esta idea del "chispazo" y continúa sobre ese tema en su reciente obra: I am a Strange Loop, traducido al español como Soy un extraño bucle (2008).

En el ajedrez es frecuente que en una posición dada alguien encuentre una opción que es absolutamente sorprendente y cambia el juego y su dinámica. Estos "chispazos" también ocurren en física o en matemáticas o en ciencias sociales.

En el ejercicio de nuestra docencia hemos tenido algún estudiante que nos presente una solución diferente , pero aunque puede ser equivocada eso no significa que no tenga ideas plausibles, Pólya nos diría no rechace esta solución, tómese su tiempo, analícela con el estudiante.

George Pólya: el razonamiento plausible. Vernor Arguedas T.

Derechos Reservados (C) 2012 Revista digital Matemática, Educación e Internet (www.tec-digital.itcr.ac.cr/revistamatematica/) 
Pólya escribió dos volúmenes de ejercicios de Análisis Matemático junto a Szegó llamado Problemas y Teoremas en Análisis Matemático I, II, el contenido de estos libros es de gran valor incluso al día de hoy.

El, Polyá siempre insistió en una gran práctica en el proceso de resolver problemas en matemáticas, como un nadador, horas y horas de práctica. Es prácticamente imposible aprender a nadar sin mojarse.

¡Cómo aprender a conjeturar? Conjeturando y luego tratando de demostrar la veracidad o falsedad de la afirmación.

Uno de los primeros problemas que planta es el siguiente dado un triángulo. ¿ se puede inscribir un cuadrado en él? O bien en el tomo I de Matemática y razonamiento plausible plantea el siguiente problema: los polinomios de grado se puede factorizar en productos de $\mathrm{n}$ factores ( reales o complejos, los ceros de multiplicidad $\mathrm{r}>1$ generan $\mathrm{r}$ factores) $i$ se puede generalizar esto a funciones real analíticas como la función seno?

Tuvo una vida muy activa como matemático, principalmente en el campo del análisis matemático, sin embargo incursionó en la teoría de números y en 1919 enunció su teoría sobre números naturales que en 1958 se demostró que no era correcta. En teoría de la combinatoria es muy conocido su teorema sobre la enumeración. Un análisis de este teorema fue publicado por los profesores Emilio Fernández y Mercedes Sánchez se puede bajar de la dirección: http://www.emis.de/proceedings/Chicho2001/Emilio-Merche.pdf

En la teoría analítica de números es muy conocida la desigualdad de Pólya-Vinogradov (1918), en la tesis doctoral de Fernando Chamizo aparece la utilización de este concepto, se puede leer en http://www.uam.es/personal_pdi/ciencias/acordoba/documentos/tesis/TesisFChamizo.pdf

A la muerte de Pólya se escribió el siguiente documento en su honor por parte de la Universidad de Stanford:

Memorial Resolution George Pólya (1887 - 1985). George Pólya, Professor Emeritus of Mathematics, died on September 7, 1985, in Palo Alto after several months of illness. George Pólya held a special place in mathematics, not only for his original and lasting contributions to pure and applied mathematics, but also as a great teacher of mathematics and for his contributions to the teaching of mathematics through his seminal work in heuristics and the methods of problem solving. He was born in Budapest on December 13, 1887, the son of Jacob and Anne (Deutsch) Pólya. Early in life he was urged by his mother to take up his father's profession, the law, and he dutifully began his work in this subject at the University of Budapest, but this lasted only for one semester. He then studied languages and literature for two years. Fond of philosophy and of literature, particularly the poetry of Heinrich Heine, some of which he translated into Hungarian, he was also attracted to physics. A philosophy professor with unusual insight convinced him that the study of mathematics and physics would help his understanding of philosophy, so he eventually came to the serious study of mathematics. This led to Pó1ya's statement: "I thought "I'm not good enough for physics and I am too good for philosophy. Mathematics is in between." At the university his physics professor was Lorand Etövös, but the faculty member to influence him most was the mathematician Lipót Fejér. Fejér drew a number of talented students into his circle: Mihály Fekete, Otto Szász, Gabor Szegö, and later Paul Erdös. Pólya spent the academic year 1910-11 at the University of Vienna, and returned to Budapest to receive his doctorate in 1912. He then went to the University of Göttingen in 1912-14 where he encountered Felix Klein, David Hilbert, Carl Runge, Edmund Landau and other eminent Göttingen professors. Even the list of Privatdozents was impressive: Hermann Weyl, Erich Hecke, Richard Courant, and Otto Toeplitz. In the spring of 1914 Pólya went to the University of Paris, where he met Emile Picard and Jacques Hadamard. In the fall of that year, at the invitation of Adolf Hurwitz, he took his first teaching position at the Eidgenössische Technische Hochschule (ETH) in Zurich, where he was to stay until 1940 and to which he returned for frequent visits later. He became a Swiss citizen, and in 1918 married Stella Vera Weber, a daughter of a professor of physics at the University of Neuchâtel. Because Mrs. Pólya grew up in Frenchspeaking Switzerland, French was the language spoken in the home, though Pólya was, of course, Hungarian, and they lived in German-speaking Switzerland. He has written mathematical 
papers in Hungarian, French, German, Italian, English, and Danish. At the ETH he became Professor in 1928. His colleagues at the ETH included Adolf Hurwitz, and later Hermann Weyl, Michel Plancherel, and Heinz Hopf. Students in his classes included Felix Bloch and Hans Staub, who later became Professors of Physics at Stanford, and the mathematician and physicist John von Neumann. At the suggestion of G. H. Hardy, Pólya was awarded the first international Rockefeller Fellowship in 1924. This was used to spend the year at Oxford and Cambridge with Hardy and J. E. Littlewood. Thus began his long friendship and collaboration with these mathematicians; one outcome of which was the famous book Hardy, Littlewood and Pólya,, Inequalities. While Pólya was at Cambridge, Hardy was in the midst of is campaign to reform the Mathematics Tripos and asked Pólya to take this examination unofficially. Hardy expected Pólya's poor showing would demonstrate that most questions were irrelevant to "modern continental mathematics." Unfortunately for Hardy's plan, Pólya's was the best performance on the examination, and he would have been named the Senior Wrangler if he had been a student. Earlier Pólya had developed a close collaboration with Gabor Szegö. Together they wrote their classic work, Aufgaben und Lehrsätze aus der Analysis, published in two volumes by Springer-Verlag in 1925. After 60 years, this work is still cited regularly and is one of the most important sources of problems in analysis. The organization was original; the problems were put together, not according to the topic, but according to the method of solution. This work has been translated into English and is still in print. The collaboration with Szegö continued with joint papers and another book, Isoperimetric Inequalities in Mathematical Physics, in 1951.

In 1933 Pólya was again selected for a Rockefeller grant, this time to visit Princeton. He spent the summer quarter of that year at Stanford. In 1940 the Pólyas left Switzerland. After two years at Brown and Smith, Pólya received an appointment at Stanford, where Gabor Szegö was Department Head. He remained at Stanford for the remainder of his academic career.

Pólya was one of the most popular teachers at Stanford. In 1948 his class on Functions of a Complex Variable was attended by Lincoln Moses and Halsey Royden, then students, and by Hugh Skilling and Fred Terman, then Head of Electrical Engineering and Dean of Engineering, respectively. Pólya became emeritus in 1953, but Fred Terman, who became Provost shortly thereafter, used the excellence of Pólya's teaching as an argument to break the strict rule of the time that emeritus faculty no longer taught. Thus Pólya became the first Professor Emeritus at Stanford recalled to active duty. He taught nearly full-time for a decade, and part-time for many years thereafter. The last course he taught was Combinatorial Analysis for the Computer Science Department in 1977 when Pólya was ninety.

Pólya's doctoral dissertation was on probability. Since there was no one at Budapest in this subject, he wrote without an advisor. He continued his study of probability, and early papers explored aspects of geometrical probabilities. He may have been the first person to use in print the term "Central Limit Theorem" to describe the normal limit law in probability. Pólya also worked on characteristic functions in probability theory, for which there is a "Pólya criterion."

One example of his work is the Pólya urn scheme, which is often used as a model to describe contagion. An offshoot of this model is the "Pólya distribution." He was the first person to investigate "random walk," a phrase he originated. In 1921 he showed that a random walk in a plane almost surely returns to its starting point, but in three dimensions it almost never returns. Pólya's most profound and difficult work is in the theory of functions of a complex variable. He was one of the pioneers, along with Picard, Hadamard, and Julia, of the modern theory of entire functions. It is an indication of the level of Pólya's contribution that the language of the subject contains such phrases as "Pólya peaks," "the Pólya representation," "the Pólya gap theorem," "the Pólya-Carlsen theorem," "Pólya's $2 z$ theorem," etc. Some of Pólya's most interesting work in this area concerns the zeros of entire functions. Work in this area is often close to the subject of the famous "Riemann hypothesis," an unproved conjecture made by Riemann in 1859 which would have important consequences in the theory of numbers. One paper of Pólya's in 1926 came close to proving the Riemann hypothesis. Although it failed to do so, it led to further developments, including some in statistical mechanics. 
Pólya was much interested in geometry and geometrical methods, especially those involving symmetry. In 1924 he described the 17 types of symmetry in the plane. The Dutch artist M. C. Escher studied this paper, and soon after, some of the additional symmetries found by Pólya began to appear in Escher's etchings and prints. Pólya and Escher corresponded with each other prior to the second world war.

Pólya's interest in symmetry emerged again in 1935 in a series of papers on isomers in chemistry, culminating in his monumental paper in 1937 on groups, graphs and molecular structures. One of the high points in the history of combinatorics, this paper showed how to count essentially different patterns, patterns that could not be changed into each other by geometrical transformation such as rotation in space. Pólya's work was accessible and comprehensive, and the principal theorem is now called the "Pólya Enumeration Theorem."

Found in any combinatorics text, it provides a powerful and subtle technique for counting graphs, geometrical patterns, and, not surprisingly, chemical compounds. In his later years Pólya became very much concerned with problems of the teaching of mathematics. Even before coming to America he had started a manuscript for his book How t Solve It, originally published by the Princeton University Press in 1945. It proved to be very popular and has now sold more than a million copies and been translated into fifteen languages.

After this came the two-volume set, Mathematics and Plausible Reasoning, (1954) again illustrating some of the heuristic principles set out earlier in How to Solve It, and in some of his articles. That was followed by a more elementary set, Mathematical Discovery, in 1962 and 1965. These works established him as the foremost advocate of problem solving and heuristics in his generation. Though he had distinguished antecedents from Descartes to Hadamard, who had also written about heuristics and the psychology of problem solving, Pólya nevertheless is the father of the current trend toward the emphasis on problem solving in mathematics teaching.

In addition to the books already cited he wrote a text, Complex Variables, with Gordon Latta in 1974, and several books and monographs: The Stanford Mathematics Problem Book (with Jeremy Kilpatrick), 1974; Mathematical Methods in Science (edited by Leon Bowden), 1963, 1977; and Notes on Introductory Combinatorics (lectures by Pólya and R. Tarjan, notes by D. Woods), 1984. His bibliography also contains 250 published articles.

George Pólya has been the recipient of many honors and awards. In addition to various honorary degrees, he was a corresponding member of the Académie des Sciences, Paris, and a member of the Hungarian Academy, the U.S. National Academy of Sciences, and the Académie Internationale de Philosophie des Sciences, Bruxelles. In 1963 he was given the Award for Distinguished Service in Mathematics by the Mathematical Association of America, and in 1968 the Blue Ribbon by the Educational Film Library Association for his film "Let us Teach

Guessing." The Society for Industrial and Applied Mathematics established the Pólya Prize in Combinatorial Theory and Its Applications, and the Mathematical Association of America gives the Pólya Prize for Expository Writing in the College Mathematical Journal. His friends will always remember George Pólya's enthusiasm, his warmth and humor, and his ready wit. George and Stella Pólya welcomed visitors to their home in College Terrace with pleasure, and George loved to recount anecdotes from his many contacts with the great mathematicians of the world.

In Professor Pólya's death, Stanford loses one of its most distinguished scholars and teachers. Those of us who were privileged to know and learn from George Pólya have lost a great teacher, colleague and friend.

Gerald Alexanderson, (University of Santa Clara)

Harold Bacon

Solomon Feferman

John G. Herriot

Halsey Royden, Chairman 
Resolución en memoria de George Pólya(1887 - 1985). George Pólya, profesor emérito de matemáticas, murió el 7 de septiembre de 1985, en Palo Alto después de varios meses de enfermedad. George Pólya ocupa un lugar especial en las matemáticas, no sólo por sus contribuciones originales y duraderas tanto en matemáticas puras y aplicadas, sino también como un gran profesor de matemáticas y por medio de sus contribuciones a la enseñanza de las matemáticas a su un trabajo fundamental en la heurística y los métodos de resolución de problemas.

Nació en Budapest el 13 de diciembre de 1887, hijo de Jacob y Ana (Deutsch) Pólya. Su madre quería que siguiera la profesión de su padre el derecho, y de manera obediente comenzó su estudio en esta materia en la Universidad de Budapest, pero esto duró sólo un semestre. A continuación, estudió lenguas y literatura durante dos años. Amante de la filosofía y de la la literatura, especialmente la poesía de Heinrich Heine, algunas de las cuales él mismo tradujo al húngaro, también se sintió atraído a la física. Un profesor de filosofía con una visión inusual lo convenció de que el estudio de las matemáticas y la física ayudaría a su comprensión de la filosofía, por lo que finalmente llegó a un estudio serio de las matemáticas. Esto llevó a la declaración de Pó1ya: "Yo pensaba" "Yo no soy lo suficientemente bueno para la física y yo soy demasiado bueno para la filosofía. La matemática está en el medio."

En la universidad fue su profesor de física Etövös Lorand, pero el académico Fejér Lipot matemático quien mayor influencia ejerció sobre él. Fejér formó un número de estudiantes con talento en su círculo: Mihály Fekete, Szasz Otto, Szegö Gabor, y más tarde Paul Erdös. Pólya pasó el curso académico 1910-11 en la Universidad de Viena, y regresó a Budapest para recibir su doctorado en 1912. A continuación, pasó a la Universidad de Göttingen en 1912-14, donde se encontró a: Felix Klein, David Hilbert, Carl Runge, Edmund Landau y otros eminentes profesores de Göttingen. Incluso la lista de otros porfesores no catedráticos de esa Universidad era impresionante: Hermann Weyl, Erich Hecke, Richard Courant, y Otto Toeplitz.

En la primavera de 1914 Pólya fue a la Universidad de París, donde conoció a Emile Picard y Jacques Hadamard. En el otoño de ese año, por invitación de Adolf Hurwitz, tomó su posición como docente en la Eidgenössische Technische Hochschule (ETH) en Zurich, donde permaneció hasta 1940 y al que regresó muchas veces . Se convirtió en un ciudadano suizo, y en 1918 se casó con Stella Vera Weber, hija de un profesor de física en la Universidad de Neuchâtel. Debido a que la esposa de Pólya creció en la zona en que se habla francés en Suiza. Esta lengua se convirtió en el lenguaje oficial en la casa de Pólya.

Pólya escribió documentos en inglés, húngaro, francés, alemán, italiano, y danés. En la ETH se convirtió en profesor en 1928. Sus colegas en la ETH incluyen a : Adolf Hurwitz, y más tarde Hermann Weyl, Plancherel Michel, y Hopf Heinz. Algunos estudiantes en sus clases fueron: Felix Bloch y Hans Staub, quien más tarde se convirtió en Profesor de Física en la Universidad de Stanford, y el matemático y físico John von Neumann. A sugerencia de GH Hardy, Pólya recibió la primera beca internacional Rockefeller en 1924. Lo que le permitió pasar el año en Oxford y Cambridge con Hardy y J. E. Littlewood. Así comenzó su larga amistad y colaboración con esos matemáticos, que tuvo como resultado el famoso libro de Hardy, Littlewood y Pólya: las desigualdades. Mientras que Pólya estaba en Cambridge, Hardy se encontraba en medio de la campaña para reformar el examen final de Matemáticas y le preguntó a Pólya que hiciera este examen no oficial. Hardy esperaba que Pólya tuviera un pobre resultado en esa prueba lo cual serviría para demuestrar que la mayoría de las preguntas no eran pertinentes para "las matemáticas modernas del continente." Por desgracia para el plan de Hardy, Pólya tuvo un resultado excelente en el examen, y hubiera sido distinguido como el mejor si hubiera sido un estudiante. Anteriormente Pólya había desarrollado una estrecha colaboración con Szegö Gabor. Juntos escribieron su trabajo clásico, Aufgaben und aus Lehrsätze Análisis der, publicado en dos volúmenes por Springer-Verlag en 1925. Después de 60 años, este trabajo aún se cita regularmente y es una de las fuentes más importantes de problemas en el análisis. La organización era original, los problemas que se pusieron juntos, no de acuerdo con el tema, pero de acuerdo con el método de solución. Este trabajo ha sido traducida al inglés y aún se sigue editando. La colaboración con Szegö continuó con otras publicaciones y documentos y otro libro, desigualdades isoperimétricas en Física Matemática, en 1951. 
En 1933, Pólya fue seleccionado de nuevo por una beca Rockefeller, esta vez para visitar Princeton. Él pasó ese trimestre de verano de ese año en Stanford. En 1940 los Pólyas dejaron Suiza. Después de dos años en Brown y Smith, Pólya recibió un nombramiento en Stanford, en donde era Szegö Gabor Jefe del Departamento. Permaneció en Stanford para el resto de su carrera académica.

Pólya fue uno de los maestros más populares en Stanford. En 1948, su clase sobre las funciones de una variable compleja contó con la presencia de Lincoln Moisés y Royden Halsey, quienes eran estudiantes, y por Hugh Skilling y Fred Terman, entonces Jefe de Ingeniería Eléctrica y Decano de Ingeniería, respectivamente. Pólya se convirtió en emérito en 1953. Fred Terman, quien se convirtió en rector poco tiempo después inició una campaña para romper la estricta regla de que los profesores eméritos no podían eneseñar, para ello utilizaba como argumento la excelencia de las clases de Polya. De este modo se convirtió Pólya en el Profesor Emérito que por primera vez era reincorporado en Stanford al servicio activo. Él enseñó casi a tiempo completo durante una década, y de tiempo parcial durante muchos años después. El último curso que enseñó fue análisis combinatorio para el Departamento de Ciencias de la Computación 1977, cuando tenía Pólya años de edad.

La tesis doctoral de Pólya fue en probabilidades. Como no había nadie en Budapest en este tema, la escribió sin un consejero. Él continuó su estudio sobre probabilidades, y sus primeros artículos fueron sobre aspectos de las probabilidades geométricas. Él pudo haber sido la primera persona en utilizar de manera escrita el término "teorema del límite central" para describir que la distribución de la suma de un número muy grande de variables aleatorias se aproxima a una distribución norma en probabilidades. Pólya también trabajó en funciones características en la teoría de probabilidades, para el cual existe un "criterio Pólya". Un ejemplo de su trabajo es el esquema de urna de Pólya, que se utiliza a menudo como un modelo para describir contagio. Una consecuencia de este modelo es la "distribución de Pólya."

Fue la primera persona en investigar "caminata aleatoria", una frase que se originó. En 1921 el demostró que una caminata aleatoria en un plano casi seguro que vuelve a su punto de partida, pero en tres dimensiones casi nunca regresa a su punto de origen.

Pólya investigó y trabajó profundamente en la teoría de funciones de una variabl compleja. Fue uno de los pioneros, junto con Picard, Hadamard, y Julia, de la teoría moderna de las funciones enteras. Es una indicación del nivel de la contribución de Pólya que en el lenguaje de funciones enteras donde aparecen frases tales como "picos de Polya", "la representación de Pólya", " el teorema de la brecha de Pólya", "el teorema de Pólya-Carlsen "," Teorema de Pólya $2 z "$ ", etc. Algunos de los más interesantes trabajos de Pólya sobre funciones enteras se refierea a los ceros de estas funciones. Este trabajos se relacionan con la famosa "hipótesis de Riemann", una conjetura no probada hasta la fecha, enunciada por Riemann en 1859 . Lo que tiene consecuencias importantes en la teoría de números. Un artículo de Pólya en 1926 estuvo cerca de probar la hipótesis de Riemann. A pesar de que no lo logró condujo a nuevos resultados, algunos de ellos en la mecánica estadística.

Pólya se interesó mucho en la geometría y métodos geométricos, especialmente aquellos que involucraban simetrías. En 1924 describió los 17 tipos de simetría en el plano. El artista holandés MC Escher estudió este documento, y poco tiempo después, se encuentra algunas de las simetrías adicionales de Polya en los grabados y pinturas de Escher . Pólya y Escher mantuvieron una correspondencia antes de la segunda guerra mundial. El interés de Pólya en la simetría surgió de nuevo en 1935 en una serie de artículos sobre los isómeros en química, que culminó en su trabajo monumental en 1937 sobre grupos, gráficos y estructuras moleculares. Este es uno de los puntos altos de la historia de la combinatoria, este trabajo mostró cómo contar patrones esencialmente diferentes, patrones que no podían ser cambiados entre sí por transformación geométrica como la rotación en el espacio. El trabajo de Pólya era accesible e integral, y el teorema principal es que ahora se llama el "Teorema de la enumeración de Pólya ". Se encuentra en cualquier texto de combinatoria, proporciona una técnica poderosa y sutil para el recuento de los gráficos, los 
patrones geométricos, y, como es lógico, los compuestos químicos.

En sus últimos años Pólya estaba muy preocupado con los problemas de la enseñanza de la las matemáticas. Incluso antes de venir a los Estados Unidos había comenzado un manuscrito de su libro "Cómo Resolverlo" que fue originalmente publicado por la Editorial de la Universidad de Princeton en 1945. Libro muy popular que ha vendido más de un millón de copias y ha sido traducido a quince idiomas.

Después de esto vino el juego de dos volúmenes, “Matemáticas y Razonamiento Plausible", (1954); de nuevo ilustrando algunos de los principios heurísticos establecidos anteriormente en "Cómo resolverlo", y en algunos de sus artículos. Esto fue seguido por un material más elemental: "El Descubrimiento Matemático", en 1962 y 1965. Estas obras lo establecieron como el más destacado defensor de la resolución de problemas y la heurística en su generación. A pesar de que había distinguido antecedentes de Descartes a Hadamard, que también habían escrito sobre la heurística y la psicología de la resolución de problemas, sin embargo, es Pólya el padre de la actual tendencia hacia el énfasis en la resolución de problemas en la enseñanza de las matemáticas. Además de los libros ya citados, escribió un texto, Variables Complejas, con Gordon Latta en 1974, y varios libros y monografías: El libro de Stanford Problemas Matemáticos (Con Jeremy Kilpatrick), 1974; Métodos Matemáticos en Ciencias (editado por Leon Bowden), 1963, 1977, y Notas sobre la introducción Combinatoria (conferencias a cargo de Pólya y Tarjan R., notas de D. Woods), 1984. Su bibliografía también contiene 250 artículos publicados.

George Pólya ha recibido numerosos honores y premios. Además de los diversos Doctor Honoris Causa, fue miembro correspondiente de la Academia de Ciencias de París, y un miembro de la Academia Húngara, la Academia Nacional de Ciencias de los EE.UU, y Academia de la Internationale de Philosophie des Sciences, Bruselas. En 1963 fue galardonado con el Premio de Servicio Distinguido en Matemáticas por la Asociación Matemática de América, y en 1968 la Cinta Azul de la Asociación de Cine de la Biblioteca para la Educación, por su película "Enseñemos a Adivinar". La Sociedad para la Matemática Industrial y Aplicada creó el Premio Pólya en Teoría Combinatoria y sus Aplicaciones, y la Asociación Americana de Matemáticas ofrece el Premio Pólya para la escritura expositiva en el College Mathematical Journal. Sus amigos siempre recordaremos el entusiasmo de George Pólya, su calidez y humor, y su agudo ingenio. George Pólya y Stella dieron la bienvenida a los visitantes en su hogar en College Terrace con calidez ya George le encantaba relatar anécdotas de sus muchos contactos con los grandes matemáticos del mundo. Con la muerte del profesor Pólya, Stanford pierde a uno de sus más distinguido académico y profesor. Aquellos de nosotros que tuvimos el privilegio de conocer y aprender de George Pólya hemos perdido a un gran maestro, colega y amigo.

Gerald Alexanderson, (University of Santa Clara)

Harold Bacon

Solomon Feferman

John G. Herriot

Halsey Royden, Presidente.

Pensar es fácil, pensar bien no es tan sencillo pero con la guía del método Pólya tal vez estemos más cerca de tener mejores seres humanos. 